\title{
Networks for prevention of violence: from utopia to action
}

\author{
Redes de prevenção à violência: \\ da utopia à ação
}

Kathie Njaine 1

Simone Gonçalves de Assis 2

Romeu Gomes 3

Maria Cecília de Souza Minayo 2

\footnotetext{
1 Claves, ENSP, Fiocruz;

Uniplac.

Avenida Brasil, 4036, sala 700, Manguinhos, 21040-361, Rio de Janeiro RJ. kathie@claves.fiocruz.br

2 Claves, ENSP, Fiocruz.

3 Instituto Fernandes

Figueiras, Claves,

ENSP, Fiocruz.
}

Abstract This article aims to discuss the experience of networks for the protection of people exposed to situations of violence or prevention networks. It is based on the concept created by Castells, who defines the information age. This study is part of the investigation "Successful experiences in the prevention of violence", carried out by the Latin-American Center for Studies on Violence Jorge Careli/ENSP-IFF/Fiocruz, in cooperation with the Secretariat for Health Survey of the Ministry of Health. The article analyzes the possibilities and limitations in the construction of networks for the prevention of violence, seeking to understand the sense of actions and movements carried out in networks. The method we used is a case study of two network initiatives in the Southern region of the country. In terms of results, in face of the difficulties of working in networks, we found it to be necessary: to break with sectorial and vertical actions; to promote constant communication and interchange of information; to permanently train the professionals and persons involved in the network, incorporating them into the protective and preventive actions; and to promote the participation of wide social sectors. In conclusion, one can affirm that the construction of a protection network involves complex steps, looking to the same problem with new eyes and a new vision for planting solutions.

Key words Network, Prevention, Violence, Child, Adolescent
Resumo Este artigo objetiva discutir a experiência de redes de proteção a pessoas em situação de violência ou redes de prevenção. Baseia-se no conceito de rede de Castells, que define a sociedade da informação. O estudo é parte da pesquisa "Experiências exitosas em prevenção da violência", realizada pelo Centro Latino-Americano de Estudos de Violência e Saúde Jorge Careli/ENSP-IFF/ Fiocruz, em convênio com a Secretaria de Vigilância à Saúde do Ministério da Saúde. O presente artigo analisa as potencialidades e os limites para a construção de redes de prevenção à violência, buscando apreender o sentido das ações e do movimento em rede. O método utilizado é o estudo de caso de duas iniciativas em rede da região Sul do país. Em termos de resultados, evidenciase que, diante das dificuldades para a atuação em rede, faz-se necessário: romper com a lógica do trabalho setorizado e verticalizado; promover o exercício constante de comunicação e de troca de informações; capacitar permanentemente os profissionais e pessoas que se envolvem na rede; incorporar a família nas ações de proteção e de prevenção; e promover a participação de amplos setores sociais. Concluindo, pode-se afirmar que a construção de uma rede de proteção demanda etapas complexas, um novo olhar para o mesmo problema e a utopia para plantar soluções.

Palavras-chave Rede, Prevenção, Violência, Criança, Adolescente 


\section{Introduction}

This article aims to discuss the experience of networks for the protection of people exposed to situations of violence or prevention networks. It is based on the concept widely used in the information society, defined by Castells ${ }^{1}$ as a web of interconnected Gordian knots. These knots determine the flow of information and communication existing between them. Approach the phenomenon violence and the protection network experiences means investigate not so much their form but much more their potential of intervening, interrupting, treating or defeating violence, to which millions of children, adolescents, women, elderly and other risk groups are exposed. Without wanting to abstract the design of these networks from the institutional viewpoint and effectiveness, in a first moment we have to try to understand how much they offer in terms of partnerships and interconnections, able to direct, attend and protect victims of violence and their families. In a second moment, we have to study the different possibilities of developing preventive actions.

According to Castells ${ }^{1}$, networks are open structures able to extend indefinitely and forming new knots. For integrating a network as a dynamic structure, it is pivotal that its members establish a connection between them, share common values and objectives, possible to be decodified in a communication process. Castells ${ }^{1}$ alerts however that, in the information society, networks can as well take the form of an instrument of power because they detain economically important technological knowledge and involve dependent work relations. As he affirms: This is the concrete meaning of articulation between the capitalist way of production and the informational way of development.

Based on this idea, Frey ${ }^{2}$ incorporates the concept of social capital, discussing the use of the new information and communication technologies for potentiating the participation of the community in the local public administration and for promoting sustainable development in the emerging network society. Doubtlessly, the use of electronic networks favors the transmission of information in real time, intensifying and widely disseminating communication. However, emphasizes the author, these experiences in electronic networks show us the need of projects democratizing the access to these new technologies like the internet.
The network would play the role of democratizing information, sharing power and decision-making. Frey ${ }^{2}$ however calls attention to the fact that communities have to prepare for the use of these new technologies, capacitating, educating them from the civic point of view (in the sense of a more efficient political participation of the community in public administration) and becoming autonomous. This author refers to the great challenge democratization of information represents in a society with deep inequalities. He thinks, however, that some social movements today directing specific actions focused on inclusion into the digital age could benefit communities by helping them to face their local problems. In this sense, community networks using free virtual spaces can help to create social capital.

The social network plays thus a basic role in the acquisition of this capital. The experience points to the possibilities and the importance of social development of certain communities, the creation of mutual trust between their members, commitment, and access to information, to institutions and to decisive power. Several studies conducted by social networks showed their relevance in the protection of persons or groups with health problems ${ }^{3}, 4$.

In the information society it is not only the density of civic organizations that determines the capacity to act collectively. Much more important is the efficiency of social networks in uniting these organizations, training them for acting in a coordinated way ${ }^{2}$.

These are some of the possibilities of using the concept network, providing the basis for understanding the networks here analyzed. Another perspective is that one, starting from communication processes and the way these networks attend socially excluded people. In this case, communication is the aggregating factor, the factor promoting equality 5 .

In this text, the social organizations, governmental or not, do not represent knots of protection against or prevention of violence nor are they a risk in an interconnected network. The creation of a network for prevention of violence nearly always requires a more intensive, continued mobilization for integrating different social actors and equipment (making use of informatization or not). Further to the need of using the same communication code, which means having the same understanding of the different forms of violence, its causes and consequences, it is necessary that the participants 
synchronize their actions in face of the urgent need of intervention.

Thus, it is impossible to create a single and final concept for prevention or protection networks. This is due to the multiple forms and specific dynamics of violence and also to the multiple experiences of social movements acting in this field, defending the rights of children, adolescents and other vulnerable groups. The dynamism and plurality of these initiatives requires investment in professional and personal attitudes, and in the way the problem violence is approached. For dealing with a deeply touching human problem, the role of these networks was to break the silence and the taboos and to overcome fear and different forms of oppression.

\section{Methodology}

The present article is part of the investigation on "Successful experiences in the prevention of violence", cleared by the ethics committee of the National School of Public Health Sérgio Arouca, of the Oswaldo Cruz Foundation (ENSP/ Fiocruz). Specifically, we visited two networks for protection against violence in Curitiba and Florianópolis. The first one is mainly focused on actions in the fields of health, education and social assistance; and the second to actions of the Department of Justice, building a link between different governmental and nongovernmental sectors. Both experiences were selected following an indication of the National Council for the Rights of Children and Adolescents.

A case study was conducted 6 for understanding how a network for prevention of violence works and for discussing more specifically the possibilities and limitations of such an experience.

We used standardized questionnaires asking for general information about each network and interviewed the professionals working there. We also used field observation. The obtained results were not submitted to specific analytical treatment. They served for contextualizing the statements.

This work also does not analyze the information from the questionnaires in terms of quantity. This information has only explanatory character and appears in the text for a better characterization of the networks.

The data collected from the focal groups were processed according to the method of interpretation of meanings, based on hermeneutic and dialectic principles of interpretation of the context, reasons and logics of statements, actions, interrelations and groups, institutions and circumstances, among other analytical bodies? The analysis and interpretation started with a comprehensive reading of the statements and ideas involved in the text and continued with an interpretation of the broader meanings articulating the models underlying the ideas.

The two models of networks we will present here are very different, although both of them are aimed at protection and support of the child, the adolescent and the juvenile under risk of violence.

\section{Network focused on health, education and social assistance}

The Network for the Protection of the Child and the Adolescent under Risk of Violence in Curitiba was created in the year 2000, with the objective to offer comprehensive assistance to children and adolescents between 0 and 18 years (not completed) of both sexes, and to their families. It attends individuals from all over the city and transfers nonresidents to the Tutorial Councils of their municipalities of origin. The network is composed by professionals from different areas, coming from several institutions, as presented in chart 1 . The structure of this network, although not of hierarchic character, is based on a municipal, as well as regional and local coordination, developing articulated or individual actions. Each of the involved institutions participates in part or fully in the identification, notification and the follow-up of ill-treatment and in preventive actions.

The formation of a network was motivated by a series of needs: the complexity of the problem requiring multiprofessional and interinstitutional approaches; awareness of the high incidence of ill-treatment of children and adolescents; the need to articulate the available resources and services for facing the problem; absolute priority given to the child and the adolescent in the municipal administration, committed with the Statute of the Child and the Adolescent (ECA); urgent need of producing information and indicators allowing to collect knowledge on the problem and to monitor the actions; need to construct strategies for preventing and defeating the problem.

For involving a great number of professionals from different sectors, the implantation of 
Chart 1

Institutions integrating the Network for the Protection of the Child and the Adolescent under Risk of Violence in Curitiba.

Municipal Health Secretariat: develops activities in the health units of nine hospitals integrating the local protection network.

Municipal Education Secretariat: integrates the local protection network. Carries out preventive actions with parents. Promotes the program Community School, opening the schools to the community during weekends, offering recreating and educative activities.

State Education Secretariat: participates in the local protection network.

Foundation for Social Assistance: offers actions of the Network for Basic and Special Social Protection; domestic visits to victimized individuals; shelters and homes; social late-shifts; reference center for infant-juvenile violence; socio-educative actions in the families; program for the eradication of child labor; programs for juvenile protagonism; program for the adolescent delinquent; basic social assistance. Counts with support from nongovernmental organizations (NGOs), which maintain shelters, provide late-shift social assistance, preventive actions and other services by means of agreements.

Municipal Secretariat for Sports and Recreation: participates with equipment, giving priority to children and adolescents, victims of violence, offering sportive activities. Counts on support from associations of residents.

Municipal Secretariat for Purveillance: introduces children and adolescents participating in the network to programs and actions like courses and nutrition programs.

Cultural Foundation of Curitiba: contributes with a network of services and cultural activities, with priority to infant-juvenile victims of violence.

Tutorial Council: exerts the functions defined by the Statute of the Child and the Adolescent.

Justice Department: contributes with prosecutory procedures in defense of childhood and adolescence.

Public Security: state police department, specialized in the defense of children and adolescents, victims of crimes.

the network occurred gradually. It started in 1999 as a pilot project, created in a meeting of the regional administration. The implantation was continued in eight regional meetings and concluded in 2002. In the end of 2005, there were nine regional meetings in the municipality and the network passed to be recognized as a creative proposal of the public administration. Currently, its formal legalization by means of a municipal law or decree is under discussion.

It is not possible to specify the number of professionals integrating the initiative because this information states only in the statistics of their institutions of origin. However, the capacitation process for implanting the network involved each region. The components are trained in seminaries, courses, workshops, and through participation in events promoted by different entities.

The network counts on the physical infrastructure of the public service (phones, com- puters, rooms, fax, and others). There is no specific financial support for its activities. Expenses with printed matters, training and infrastructure are, as far as possible, covered with funds made available by solidary organisms. The administrators of the networks considered the financial resources available for 2005 insufficient for a full development of the protective/preventive actions.

The degree of involvement of the institutions frequently changes, a fact that hampers their articulation. The evaluation of the municipal and regional Coordinations shows better results than the local Coordinations, especially as refers to the presence of their leaders in the meetings. With respect to mutual support between organizations, division of responsibilities and flow of information, the regional and local networks showed to be more participative. The local network, essential for execut- 
ing the actions, is the most vulnerable and overloaded with work.

The cooperation between work groups from different local sectors, formally or informally articulated, is providing some answers to the problems of violence inside the communities themselves. For acting at closer distance to the violent situations, they frequently develop independent (and sometimes isolated) actions with respect to this problem. In this sense, the role played by the network is of utmost importance for giving support to the local level, the communities and small groups engaged in this task.

The network has no statistical data collection nor has it centralized records describing the actions and means used in the protection and prevention of violence against children, adolescents and their families. The Regional Coordinations dispose of records in form of summaries or records of meetings. The form for notification of violence has been used for following the cases and help to construct a $d a$ ta bank on violence against children and adolescents in the municipality.

The practice of evaluation of the results of the protective and preventive actions promoted by the network is not yet established. This is unfortunate because it hinders an appropriate appreciation of the results. From the viewpoint of the participants of the initiative, the quality of the preventive actions and of the assistance given to the victims and their families is increasingly improving.

Based on the presently existing difficulties, the components of the network identify the following needs for the future: 1) continued training and creation of awareness of the multiplier teams per region; 2) structuring of the services for guidance and support of families exposed to domestic violence; 3 ) better integration with the Tutorial Councils; 4) improvement of intersectorial and integrated work; 5) extension of the network to the private sector engaged in education and health; 5) informatization of the obligatory Notification Form; 6) legalization of the Protection Network; and 7) efforts for inclusion of the assistance services for victims of violence in the roll of priorities.

An important premise brought by the network in Curitiba for this new concept of integrated and intersectorial work is the understanding that this task means constant construction. The experience shows that the implantation of a network does not require massive public or private investment. Above all, it re- quires a new, more attentive vision of professionals, relatives and other responsible for children and adolescents, to be able to prevent, guide, diagnose and give assistance by means of the legal instruments. In this sense, one should not necessarily think about creating new services or programs (unless they need to be reorganized for whatever reason), but rather about integrating the established ones, counting on aware and engaged people.

\section{Network focused on the Justice Department}

This network seated in Florianópolis was created in October 2004, under the leadership of the State Justice Department. In the course of the following nine months, the 16 regional centers of the state were included, corresponding to a total of 295 involved municipalities, among them the capital of the state. Its creation was motivated by the high rates of ill-treatment registered by the Tutorial Councils. The target population involves children and adolescents up to 18 years of age, of both sexes.

The network was formalized by means of a cooperation agreement signed by several institutions, creating in the State of Santa Catarina the instrument Notification of Ill-treatment of a Child or Adolescent (APOMT), presently being instituted. Differently from the city of $\mathrm{Cu}$ ritiba, where the health sector played a fundamental role as a disseminator, in Florianópolis it was the Justice Department who aggregated other institutions to the discussions of the network.

The central idea guiding the construction of the network of Santa Catarina is that of an information system capable of contributing with strategic data to all institutions involved with violence against children and adolescents. The information system is considered a potentiator in the definition of preventive actions, seeing that access to organized and reliable information can support public policies directed to local problems.

A campaign - developed by a communication company and promoted during two years in the electronic media - approaching the theme violence against children and adolescents and its prevention touched the public opinion. Since this campaign, the Justice Department is mobilizing partners for participating in the network. The institutions involved in the pro- 
tective and preventive activities are identified in chart 2.

Besides these partner institutions, the management of the APOMT also mentions the participation of the following organisms in the network: Mauricio Sirotsky Sobrinho Foundation, National Council of the Child and the Adolescent, Syndicate of Private Educational Establishments, Society of Pediatricians of Santa Catarina, among others. The actions developed by these organisms in partnership with the network, however, are not specified.

The network counts with an Administrative and Technical Committee, composed by public servants of different organisms. All professionals participating in the regional implantation of the program are trained and made aware of the need of giving assistance through a network.

The institutions participating in the agreement provide the network with telephones, fax, computers, rooms and vehicles. There are no specific funds available for maintaining the activities of this initiative; therefore it depends on funds made available by the participating organisms.

The Management of the network evaluated as positive the articulation between the partner institutions as refers to: regular participation in meetings, assiduous activities of the responsible, mutual support between programs, division of responsibilities and reference and contra-reference of information.

Among the difficulties in the development of the preventive actions pointed out by the Management, we emphasize: insufficient publication of pedagogical material; lack of promotion of the program in the media; lack of a permanent specialized team for giving assistance to the cases of ill-treatment in each municipality and technical support for the other professionals.

There is still a series of activities to be explored by the network, for example: the implementation of the program in 293 municipalities - in every school, health unit, police station, tutorial council, justice department, service program and in the Council for the Rights of Children and Adolescents of each municipality. At the time this investigation was concluded, the training activities and the promotion of this proposal had only occurred on regional level.

The results of the protective and preventive actions coordinated by the network are still not subject to evaluation because the implantation of the program is still in course. There are still no statistics of children and adolescents that were protected by the actions of the network. There are no data with regard to the proposed assistance to the families of the victimized children and adolescents. Different record sheets were created, aimed at systemizing the information in each of the participating institutions; public safety, health, education, tutorial councils, programs, all of them still being implanted.

In future, all professionals participating in the network will use these forms in cases of suspected or confirmed ill-treatment and submit them to the Tutorial Council. This entity will remit them to the prosecutor's office, where they will be included in the data bank. The prosecutors keep an online data bank providing periodical reports, made available in the page of the Justice Department of the State of Santa Catarina in the Internet. The components of the network opted for this form of statistical records of their actions.

The actions carried out in the network system, mainly through flow of information about notified violence, still depends on improved conditions provided by the State for the proper functioning of the initiative, as there are: greater financial support, less paperwork in the flow of information, integration of the programs responsible for children and adolescents and others, with capacity of improving the network of the State.

The documents underlying the implantation include some important principles, although still very far from being put in practice. One of them refers to the need of dealing with offenders, by means of providing assistance and guidance instead of only punishing them. This document also states the need of approaching the family in the sense of protection. A third aspect of extreme relevance is the training of professionals.

At the time the field research was carried out, the network was in process of implantation and its members were still trained in the notification of ill-treatment of children and adolescents and how to proceed with this notification. 
Chart 2

Institutions integrating the program Notification of Ill-treatment of Santa Catarina.

State Secretariat of Education and Innovation: promised to implant the APOMT program in the schools integrating education system of the state; include it in the political-pedagogical projects of the school units; incorporate it in the courses for education of professionals in general; organize multiplying processes in the region; offer technical support to teachers and directors, to assure compliance with the state law referring notification; establish articulations between all partners on state and municipal level.

State Secretariat of Health: took the responsibility of integrating the APOMT program and the norms for its execution in a directive already existing in the state. This Secretariat promised to: distribute a copy of the directive and of the notification form in all health units; offer technical support and training of personnel in the correct care and assistance of victims of ill-treatment; indicate technicians for integrating a technical team responsible for creating awareness and training the executive partners in the regional units.

Also committed with the National Policy of Reduction of Mortality and Morbidity from Accidents and Violence, it proposed to ensure promotion, amplification and consolidation of prehospital care; provide for interdisciplinary and intersectorial assistance for victims of violence; and to structure and consolidate recuperation and rehabilitation services.

State Secretariat of Public Safety and Defense of the Citizen: promised to institute the APOMT program by means of a directive in all police stations and similar organisms as well as to establish norms for its execution. It also foresees: technical support and training of professionals; presence of professionals in the health units registering aggravated battery or carnal knowledge, so that the victims must not be taken to the police station; physical examination of aggravated battery or carnal knowledge in the health unit where the problem was diagnosed by the medical examiner of the Medical Jurisprudence Institute (IML); physical adaptation of police stations for ensuring privacy to the victims of sexual crimes and ill-treatment; provide a technical team, responsible for creating awareness and training regional executive partners; insertion of the issue in the training and capacitation courses of police institutions.

State Secretariat for Social, Urban and Environmental Development: committed itself to promote the program in a meeting of regional social development managers, and organizing in cooperation with them multiplication processes in the regions; establish hours/class for this topic in the education of professionals, giving assistance to children and adolescents; offer technical support to professionals working in this area; favor the already existing programs in support of children and adolescents victims of ill-treatment and their families; and foment the creation of such programs in municipalities where they do not exist at yet.

National Union of Municipal Education Directors of the State of Santa Catarina: committed itself to distribute a copy of the APOMT to the mayors and to convoke its partners to support the program.

Justice Department of the State of Santa Catarina: committed itself through its Center for Operational Support of Childhood and Adolescence to designate prosecutors for acting in the field of children and juveniles and in criminal law for the entire state of Santa Catarina; convoke prosecutors in this field, for discussing the establishment of the program in their respective regions; process the information received from all partners regarding Notification of Ill-treatment, organize it in a data bank and publish six-monthly reports.

Santa Catarina Forum for the End of Violence and Infant and Juvenile Sexual Abuse: took over the following responsibilities - amplify training activities; integrate its members to the program; supervise the distribution of a copy of APOMT to the regional coordinators and professionals for acting as multipliers of actions directed to prevention of the different forms of violence.

Association of Tutorial Counselors of Santa Catarina: proposed to supervise the distribution of a copy of APOMT to all Tutorial Councils; include the topic in the training of the counselors; convoke its associates for supporting and participating in the dissemination and evaluation of the network. 


\section{The construction of prevention networks - other experiences}

There is still no consolidated map of networks acting in the different regions of the country. We know however that many networks, even some still under construction in different regions, show success in some important items in the prevention of violence in general and in the protection of persons exposed to violent situations.

The multiple and many times improbable partnerships, mainly between the State, the private sector and society, are a characteristic of the networks. There is an example for such an integrated action in São Paulo - the Reference Center for Victims of Violence of the Sedes Sapientiae Institute, whose objective, among others, is to create protection networks for persons exposed to domestic violence. To that purpose, this team is creating poles in different communities of the city with public or private funds, gathering parents, educators and young people. In these encounters they promote dramatization workshops, lectures and interactive games, in which the participants are given the opportunity to think about violence, its causes and the damage it produces.

The principle underlying the actions of these poles is to make people aware of their rights and duties as citizens, above all with regard to the changes in the reality of violence, marking the life of many families. For this reason, awareness, promotion of self-esteem turn people capable of taking active part in this change, optimization of local resources and strengthening of an assistance network are priorities, giving visibility to the people, make them grow with them.

The Reference Center for Victims of Violence created a methodology for the institution of poles, systemizing this important initiative. The network acts in different stages of prevention: identification and recognition of risk signals, notification, assistance to the child, adolescent and their family, legal assistance when necessary. Whenever possible, it also attends the offender.

The project Citizen Rescue, also created by the Center, directed to potentiating local mostly scarce - resources, works with social inclusion of children and adolescents living in poor communities. This project works as a network for preventing violence in one of the neighborhoods in São Paulo. It mobilizes local health, social assistance, community, sportive, and educational resources. Its main goal is to educate the adolescents for becoming multipliers of preventive actions against violence and promotion of citizenship 8 .

\section{Conclusions}

With this work, we aimed to present a promising and growing movement acting through networks for promoting protection and prevention of violence against children and adolescents and turning this problem into a public cause, shared by the most different governmental actors, NGOs and the private enterprise. These initiatives have a positive impact by breaking the invisibility, the tacit assent and the silence that pervade the greater part of forms of violence since the childhood. The act of "unnaturalizing" the practice of violence implies in splitting, in destroying many of the pillars that sustain the antiquated cultural values anchored in Brazilian history, perpetuating harmful myths for childhood and adolescence. Such myths, preconceptions and discriminating attitudes tend to reproduce themselves unless they are stopped by civilizatory intervention, in the Brazilian case consolidated in the Statute of the Child and the Adolescent. The task of the networks is not only large-scale protection, but to awake the awareness of violence, its causes and consequences, as a problem that affects people individually and collectively. Besides, they also show that violence against children and adolescents is abominable but curable.

It is important to emphasize that, as mentioned by Castells 1 , the network strategy harmonizes with the most recent forms of management of the post-industrial societies. By taking care of the healthy growth and development of these small citizens, the network makes public and politicizes a typical problem of the patriarchic society centered on the adult, only possible to be defeated through solidarity and converging partnerships, in which every member takes care of his part and communicates with the others.

This analysis shows that for being efficient, network activity needs some requisites constructed during the process: horizontality of sectors; representation of different institutions through their leaders; co-responsibility; shared resources and information; autonomy of institutions for deciding, planning and executing 
actions directed to the community; capacity of incorporating new partners and to allow the egress of institutions and persons; and sustainability. These aspects alone do not ensure the success of a movement but they are prerequisites and guidelines for action.

The major problems hampering the networks are: different understandings; political divergence; personal pride; conflict between participating organisms regarding their role; rotation of personnel in the partner institutions; different work dynamics; and incompatibility of references.

Another difficulty common to the analyzed networks is the inclusion of the family in the protective and preventive actions, beginning at the moment the victimized child or adolescent is assisted. Although the networks of Curitiba and Florianópolis inform that they are attending families, the managers and technicians recognize the difficulty and the deficiencies of these actions. Frequently, only the mother is included in the action, and even so irregularly. The inclusion of the family in cultural transformation processes is a great challenge not only for the networks but also for other kinds of services dealing with persons exposed to violence?.

In face of the requisites and problems evidenced, one concludes that the construction of networks - for being a new system of action requires investment in training and motivation of the participants, so that all of them can communicate in an agile and clear way. This is a great and permanent challenge, which requires participation of a great variety of social sectors, for example the communication media, the health area and community movements. We are speaking about information allowing transformation not only through acquisition of formal knowledge about violence, but - principally - through promoting citizenship as a form to combat violence. The examples of capacitation pointed out in this article illustrate an ini- tiative in process, in which the knowledge and the engagement of all participants make the difference and form the knot of the so much commented "intersectoriality".

The study also evidences the need for investing in external follow-up and evaluation, pari passu with self-evaluation. The two presented examples show networks acting on the basis of ample governmental resources. Several other initiatives count on local resources, congregating NGOs and communities, which together exert pressure and demand for participation of the governmental services. There are still other initiatives carried out by the private enterprise moved by the idea of social responsibility. But the official recognition of the network practice is not enough for maintaining interconnections. Many of the interviewed professionals consider important that the communities themselves recognize the importance of interconnected partnerships, as also expressed by Mattelart $\&$ Mattelart 5 . In this sense, the visibility of the equipments of the state on local level, being present and active, is fundamental for making people trust in the institutions and their actions. On the other hand, the influence of the institutions integrating the networks is decisive for showing to local, municipal, state, federal and international 10 authorities how harmful violence is in all its manifestations.

In conclusion, one can affirm that the construction of a network involves complex stages, a new understanding of an old problem, utopistic vision for planting solutions, besides the need to abandon the old system - each sector working isolated and under a vertical hierarchy. To face this challenge is the wish of many professionals engaged in the creation of this initiative, and the result is doubtlessly a transformation of all participants into more understanding people, better prepared for their specific activities. The knot being created between the different cooperating partners makes people grow beyond themselves.

\section{Collaborations}

K Njaine, SG Assis, R Gomes and MCS Minayo have contributed equally during the manuscript preparation. 


\section{References}

1. Castells M. A sociedade em rede. São Paulo: Paz e Terra; 2000.

2. Frey K. Desenvolvimento sustentável local na sociedade em rede: o potencial das novas tecnologias de informação e comunicação. Rev Sociol Polit 2003; 21:165-85.

3. Andrade GRB, Vaitsman J. Apoio social e redes: conectando solidariedade e saúde. Rev C S Col 2002; 7(4):925-34.

4. Marteleto RM. Análise das redes sociais: aplicação nos estudos de transferência da informação. Ci Infi 2001; 30(1):71-81.

5. Mattelart A, Mattelart M. História das teorias da comunicação. São Paulo: Edições Loyola; 2000.

6. Becker HS. Método de pesquisa em ciências sociais. São Paulo: Hucitec; 1993.
7. Gomes R, Souza ER, Minayo MCS, Silva CFR. Organização, processamento, análise e interpretação de dados: o desafio da triangulação. In: Minayo MCS, Assis SG, Souza ER, organizadoras. Avaliação por triangulação de métodos: abordagem de programas sociais. Rio de Janeiro: Ed. Fiocruz; 2005. p. 185-221.

8. Fundação Abrinq. $\mathrm{O}$ fim da omissão: a implantação de pólos de prevenção à violência doméstica. São Paulo: Fundação Abrinq; 2002. Prêmio Criança 2002.

9. Deslandes SF, Assis SG, Njaine K, Ximenes LF, Gomes R, Cabral CA, et al. Famílias: parceiras ou usuárias eventuais? Análise de serviços de atenção a famílias com dinâmica de violência doméstica contra crianças e adolecentes. Rio de Janeiro: Claves/ENSP/ Fiocruz; Brasília: Unicef; 2004.

10. Organização Mundial de Saúde. Relatório mundial sobre violência e saúde. Genebra: OMS; 2002.

Article presented in 6/03/2006

Approved in 30/03/2006

Final version presented in 7/04/2006 